\title{
PENGGUNAAN MEDIA GAMBAR SEBAGAI UPAYA MENINGKATKAN HASIL BELAJAR MATA PELAJARAN ILMU PENGETAHUAN ALAM (IPA) DI KELAS I MADRASAH IBTIDAIYAH AN-NUR KOTA CIREBON.
}

\author{
H. Bunyamin, Amanah
}

\begin{abstract}
ABSTRAK
Media merupakan salah satu alat yang sangat penting bagi kegiatan pembelajaran. Media yang tepat akan menunjang kegiatan belajar-mengajar yang yang berlangsung di kelas. Media adalah perantara/ penghubung antara guru dengan murid. Gambar dapat dipergunakan sebagai media pendidikan dan mempunyai nilai-nilai pendidikan bagi peserta didik yang memungkinkan belajar secara efisien peserta didik yang berkaitan dengan pemanfaatan media gambar dalam pembelajaran IPA di MI. Namun kenyataannya terkadang guru belum mampu menggunakan media pembelajaran yang tepat dalam kegiatan pembelajaran di kelas.

Prestasi belajar merupakan ukuran tingkat keberhasilan seseorang dalam mempelajari sesuatu. Presetasi belajar seorang dapat dilihat berdasarkan skor yang diperolehnya dalam menyelesaikan soal-soal ujian terkait dengan bahan yang sedang dipelajarinya. Setiap pembelajaran tentunya mengharapkan hasil belajar yang maksimal, namun pada kenyataanya masih terdapat siswa yang memperoleh nilai IPA dibawah KKM.

Penelitian ini bertujuan untuk memperbaiki hasil belajar siswa dengan penggunaan media gambar pada mata pelajaran IPA di kelas I MI An-Nur Kota Cirebon, meningkatkan prestasi hasil belajar IPA di kelas I dan pengaruh media gambar sebagai upaya meningkatkan hasil belajar IPA di Kelas I MI An-Nur Kota Cirebon.

Penelitian ini merupakan Penelitian Tindakan Kelas (PTK) dan teknik pengumpulan data berupa observasi, soal tes, dan dokumentasi. Populasi dalam penelitian ini adalah semua siswa MI An-Nur Kota Cirebon sebanyak 375 siswa dan menggunakan Cluster sample yaitu kelas I.1 sebanyak 23 siswa.

Data yang diperoleh kemudian diolah dengan menggunakan Microsoft Excel 2010. Dari hasil pengolahan data tersebut didapat kesimpulan bahwa Berdasarkan hasil keseluruhan dari mulai pra siklus, siklus I sampai siklus II, hasil belajar yang diperoleh siswa kelas I dengan menggunakan media gambar mengalami peningkatan hasil belajar setiap siklusnya. Pada pra siklus diperoleh rata-rata 60,04 , siklus I diperoleh rata-rata 72,17 . Nilai tersebut mengalami peningkatan $12,13 \%$, siklus II diperoleh nilai rata-rata 86,52 nilai tersebut mengalami peningkatan sebesar 14,35.
\end{abstract}




\section{Pendahuluan}

\section{Latar Belakang}

Pendidikan adalah usaha sadar yang dilakukan oleh keluarga, masyarakat dan pemerintah, melalui kegiatan bimbingan, pengajaran dan latihan yang berlangsung di sekolah dan di luar sekolah sepanjang hayat, untuk mempersiapkan peserta didik agar dapat memainkan peranan dalam berbagai lingkungan hidup secara tepat di masa yang akan datang. Pendidikan adalah pengalaman-pengalaman belajar terprogram dalam bentuk pendidikan formal dan non formal, dan informal di sekolah, dan di luar sekolah yang berlangsung seumur hidup yang bertujuan optimalisasi pertimbanagan kemampuan-kemampuan individu, agar dikemudian hari dapat memainkan peranan hidup secara tepat.

Pendidikan dalam arti luas tercantum dalam Undang-Undang RI No.20 Tahun 2003 tentang Sistem Pendidikan Nasional (Ruswandi, 2008 : 57)

Dikatakan bahwa :

Pendidikan adalah usaha sadar dan terencana untuk mewujudkan suasan belajar dan proses pembelajaran agar peserta didik secara aktif mengembangkan potensi dirinya untuk memiliki kekuatan spiritual keagamaan, pengendalian diri, kepribadian, kecerdasan, akhlak mulia, serta keterampilan yang diperlukan dirinya, masyarakat, bangsa dan negara.

Belajar adalah suatu proses yang kompleks yang terjadi pada diri setiap orang sepanjang hidupnya. Proses belajar itu terjadi karena adanya interaksi antara seseorang dengan lingkungannya. Oleh karena itu, belajar dapat terjadi kapan saja dan dimana saja. Salah satu pertanda bahwa seseorang itu telah belajar adalah adanya perubahan tingkah laku pada diri orang itu yang mungkin disebabkan oleh terjadinya perubahan pada tingkat pengetahuan, keterampilan dan sikapnya.

Apabila proses belajar itu diselenggarakan secara formal di sekolah-sekolah, tidak lain ini dimaksudkan untuk mengarahkan perubahan pada diri siswa secara terencana, baik dalam aspek pengetahuan, keterampilan, maupun sikap. Interaksi yang terjadi selama proses belajar tersebut dipengaruhi oleh lingkungannya, yang antara lain terdiri atas murid, guru, petugas perpustakaan, kepala sekolah, bahan atau materi pelajaran (buku, modul, selebaran, majalah, rekaman video atau audio, 
dan yang sejenisnya), dan berbagai sumber belajar dan fasilitas (proyektor overhead, perekam pita audio dan video, radio, televisi, komputer, perpustakaan, laboratotium, pusat sumber belajar, dan lain-lain).

Perkembangan ilmu pengetahuan dan teknologi semakin mendorong upayaupaya pembaruan dalam pemanfaatan hasil-hasil teknologi dalam proses belajar. Para guru dituntut agar mampu menggunakan alat-alat yang dapat disediakan oleh sekolah, dan tidak menutup kemungkinan bahwa alat-alat tersebut sesuai dengan perkembangan dan tuntutan zaman.

Guru sekurang-kurangnya dapat menggunakan alat yang murah dan efisien meskipun sederhana dan bersahaja tetapi merupakan keharusan dalam upaya mencapai tujuan pengajaran yang diharapkan. Disamping mampu menggunakan alat-alat yang tersedia, guru juga dituntut untuk dapat mengembangkan keterampilan membuat media pembelajaran yang akan diguanakannya apabila media tersebut belum tersedia untuk itu guru harus memiliki pengetahuan dan pemahaman yang cukup tentang media pembelajaran yang meliputi (Hamalik, 1994 : 6) : a. media sebagai alat komunikasi guna lebih mengefektifkan proses belajar mengajar; b. Fungsi media dalam rangka mencapai tujuan pendidikan; c. Seluk beluk proses belajar; d. Hubungan antara metode mengajar dan media pendidikan; nilai atau manfaat media pendidikan dalam pengajaran; f. Pemilihan dan penggunaan media pendidikan; berbagai jenis alat dan teknik media pendidikan; h. Media pendidikan dalam setiap mata pelajaran; i. Usaha inovasi dalam media pendidikan.

Dengan demikian, dapat disimpulkan bahwa media adalah bagian yang tidak terpisahkan dari proses belajar mengajar demi tercapainya tujuan pendidikan pada umumnya dan tujuan pembelajaran di sekolah pada khusunya.

Setiap ilmu yang disampaikan dalam proses pembelajaran hendaknya ditujukan untuk mendorong rasa ingin tahu dan pengembangan anak didik terhadap dunia mereka dimana mereka tinggal. IPA mempelajari banyak hal yang sangat diperlukan untuk menjalani hidup kedepannya dari mulai belajar mengenal anggota tubuhnya, hewan, tumbuh-tumbuhan, bumi, matahari, dan lingkungan sekitarnya. 
Hasil belajar yang baik merupakan komponen yang harus diwujudkan oleh setiap siswa. Untuk itu dalam proses pembelajaran seorang guru harus mampu melakukan berbagai usaha untuk dapat membantu siswa dalam proses pencapaian hasil belajar. Salah satu upaya guru yang dapat diterapkan untuk meningakatkan hasil belajar dalam mengikuti proses pembelajaran, selain dengan menggunakan model-model pembelajaran juga dapat menggunakan metode dan media pembelajaran, karena dengan ini diharapkan akan tumbuh minat pada diri siswa untuk belajar.

Dalam kegiatan pendidikan seorang guru merupakan salah satu faktor penunjang keberhasilan peserta didik, tidak hanya dari pengetahuan dan ilmu yang di miliki, tetapi juga cara penyampaian dan media yang digunakan dalam kegiatan pembelajaran. Media yang kreatif dan menarik sangat dibutuhkan siswa dalam pembelajaran Ilmu Pengetahuan Alam (IPA). Karena ilmu pengetahuan alam merupakan ilmu yang berhubungan langsung dengan alam, oleh karenanya seorang guru harus mengajar IPA dengan cara mengaitkan pelajaran dengan konteks kehidupan, salah satu caranya yakni dengan menampilkan gambargambar sesuai dengan aslinya, misalnya dalam materi benda langit, seorang guru dapat menggunakan gambar matahari, bulan, bintang, bagian-bagian tubuh dan yang lainnya sebagai media.

Dari hasil nilai Ujian Tengah Semester yang diadakan pada tanggal 3-12 Maret 2015 di MI An-Nur kota Cirebon, terdapat 10 dari 24 siswa yang ada di kelas I.1 yang belum memenuhi nilai KKM pada mata pelajaran Ilmu Pengetahuan Alam (IPA). KKM pada mata pelajaran Ilmu Pengetahuan Alam sendiri yaitu 7,0 atau (70). Dalam hal ini tentunya bukan satu-satunya masalah yang timbul dari siswa yang kurang siap dalam mengahadapi ujian, atau faktor lainnya yang timbul dari siswa, tetapi banyak faktor yang mempengaruhi diantaranya dari guru yang belum menggunakan media yang sesuai dengan kebutuhan siswa dan yang dapat meningkatkan kreativitas siswa, sehingga proses pembelajaran akan lebih menyenangkan dan mencapai tujuannya.

Pembelajaran IPA merupakan upaya guru dalam membelajarkan siswa melalui penerapan berbagai model, metode dan media pembelajaran yang sesuai dengan 
kondisi dan karakteristik yang dimiliki oleh siswa SD/MI. Ada anggapan bahwa mata pelajaran IPA itu sebagai pelajaran eksak yang bagi sebagian siswa pembelajaran yang serius, sedangkan dalam proses pembelajaran itu harus menyenangkan. Sehingga siswa dalam proses pembelajaran menjadi bergairah, tanpa tekanan, dan semangat dalam menerima pelajaran.

Guru dalam memberikan pembelajaran dibutuhkan berbagai model, metode, media yang dapat menarik motivasi belajar anak sehingga dapat meningkatkan hasil belajarnya. Banyak model, metode dan media yang bisa membuat siswa tertarik. Salah satunya adalah menggunakan media gambar yang menarik minat siswa yang bisa juga dikembangkan dalam proses pembelajaran IPA di kelas. Melalui media gambar diharapkan siswa akan terpusat perhatiannya sehingga pembelajaran akan lebih bermakna.

Sesuai dengan UU Sisdiknas No. 20 tahun 2003 pasal 40 yang berisi : menciptakan suasana pendidikan yang bermakna, menyenangkan, kreatif, dinamis, dan dialogis. Maka mata peajaran IPA dapat dibuat menjadi menyenangkan, tergantung bagaimana niat dan kemauan guru untuk menciptakannya. Pembelajaran yang dikemas dalam situasi yang menyenangkan, jenaka, dan menggelitik sangat diharapkan oleh anak didik saat ini yang sangat rawan stres karena saratnya materi ajar yang harus dikuasai.

Kata media berasal dari bahasa Latin medius yang secara harfiah berarti 'tengah', 'perantara' atau 'pengantar'. Dalam bahasa Arab, media adalah perantara atau pengantar pesan dari pengirim kepada penerima pesan. Gerlach \& Elly (1971) mengatakan bahwa media apabila dipahami secara garis besar adalah manusia, materi, atau kejadian yang membangun kondisi yang membuat siswa mampu memperoleh pengetahuan, keterampilan, atau sikap. Dalam pengertian ini, guru, buku, teks, dan lingkungan sekolah merupakan media. Secara lebih khusus, pengertian media dalam proses belajar mengajar cenderung diartikan sebagai alatalat grafis, photografis, atau elektronis untuk menangkap, memproses, dan menyusun kembali informasi visual atau verbal (Arsyad, $2014: 3$ ).

Heinich, dan kawan-kawan (1982) dalam Arsyad (2014 : 3) mengemukakan istilah medium sebagai perantara yang mengantar informasi antara sumber dan 
penerima. Jadi, televisi, film, foto, radio, rekaman, audio, gambar yang diproyeksikan, bahan-bahan cetakan, dan sejenisnya adalah media komunikasi. Apabila media itu membawa pesan-pesan atau informasi yang bertujuan instruksional atau mengandung maksud-maksud pengajaran maka media itu disebut media pembelajaran. Sejalan dengan batasan ini, Hamidjojo dalam Latuheru (1993) memberi batasan media sebagai semua bentuk perantara yang digunakan oleh manusia untuk menyampaikan atau menyebar ide, gagasan, atau pendapat sehingga ide, gagasan atau pendapat yang dikemukakan itu sampai kepada penerima yang dituju.

Sedangkan Marshall Mc. Luchan (dalam Sihkabuden, 2002:16) mengungkapkan bahwa media adalah sarana yang disebut channel (saluran), karena pada hakikatnya media telah memperluas dan memperpanjang kemampuan manusia untuk merasakan, mendengar, dan melihat dalam batas jarak dan waktu tertentu (Muslich, $2011:$ 132).

Media adalah sumber belajar selain guru, media juga bisa disebut sebagai penyalur atau penghubung pesan ajar yang diadakan atau diciptakan secara terencana oleh para guru atau pendidik (Munadi, $2010: 5$ ).

Gagne' dan Briggs (1978) dalam Arsyad (2010 : 4) secara implisit mengatakan bahwa media pembelajaran meliputi alat yang secara fisik digunakan untuk menyampaikan isi materi pengajaran, yang terdiri dari antara lain buku, tape recorder, video camera, video recorder, film, slide (gambar bingkai), foto, gambar, grafik, televisi, dan komputer. Dengan kata lain, media adalah komponen sumber belajar atau wahana fisik yang mengandung materi instruksional di lingkungan siswa yang dapat merangsang siswa untuk belajar.

Dalam penelitian tindakan kelas ini saya menggunakan media visual yakni dengan gambar-gambar untuk meningkatkan hasil belajar, karena media visual dapat memperlancar pemahaman dan memperkuat ingatan. Visual (gambar, filmfilm yang bergerak dan tidak bersuara, peta, globe (bola dunia), gambar atau lukisan, bagan, contoh, dan museum (Khalifah, Quthub, 2015 : 117).

Media berbasis visual (image atau perumpamaan) memegang peran yang sangat penting dalam proses belajar. Media visual dapat memperlancar 
pemahaman (misalnya melalui elaborasi struktur dan organisasi) dan memperkuat ingatan. Visual dapat pula menumbuhkan minat siswa dan dapat memberikan hubungan antara isi materi pelajaran dengan dunia nyata. Dalam hal ini peneliti menggunakan media gambar yang berguna untuk menghubungkan materi pelajaran dengan siswa. Gambar dapat mengatasi batasan ruang dan waktu. Tidak semua benda, objek atau peristiwa dapat dibawa ke kelas, dan anak-anak tidak selalu dapat dibawa ke objek/ peristiwa tersebut. Sehingga gambar/ foto dapat mengatasi hal tersebut.

Peneliti melakukan penelitian tindakan kelas ini bertujuan untuk memperbaiki hasil belajar mata pelajaran IPA di kelas I MI An-Nur Kota Cirebon. IPA merupakan mata pelajaran yang sangat penting bagi peserta didik terutama anak kelas rendah yakni kelas I. Anak kelas rendah harus benar-benar bisa menguasai mata pelajaran IPA, karena IPA mempelajari tentang alam sekitar yang ada disekitar mereka, seperti materi tubuhku, anak harus memahami apa saja bagianbagian tubuh mereka dan kegunaan bagian tubuh mereka. Kelas I merupakan kelas permulaan dimana kita sebagai seorang pendidik harus mampu membuat peserta didiknya menguasai materi pelajaran dan mencapai tujuan dari pembelajaran. Agar kedepannya peserta didik akan lebih siap dalam menghadapi mata pelajaran atau materi yang lebih berat lagi dikelas selanjutnya (atas).

\section{Perumusan Masalah}

2.1 Identifikasi masalah

1) Wilayah Kajian

Wilayah kajian dalam penelitian ini adalah penggunaan media gambar sebagai peningkatan hasil belajar siswa dalam mata pelajaran Ilmu Pengetahuan Alam (IPA).

2) Pendekatan penelitian

Penelitian ini dilaksanakan dengan menggunakan metode Penelitian Tindakan Kelas. PTK dapat diartikan sebagai upaya yang ditujukan untuk 
memperbaiki proses pembelajaran atau memecahkan masalah yang dihadapi dalam pembelajaran. Penelitian ini yang berperan sebagai guru adalah peneliti sendiri dalam melaksanakan pengajaran dengan menggunakan media gambar. Penelitian ini dilaksanakan melalui empat tahap kegiatan. Siklus kegiatan keempat tahapan itu adalah perencanaan, tindakan, observasi dan refleksi.

\subsection{Pembatasan masalah}

1) Lokasi penelitan bertempat di Madrasah Ibtidaiyah An-Nur Kota Cirebon.

2) Variabel penelitian media gambar (variabel independen) dan hasil belajar siswa (variabel dependen)

3) Pelaksanaan penelitian tindakan kelas (PTK) dilaksanakan di kelas I.1

\subsection{Pertanyaan penelitian}

Berdasarkan identifikasi masalah tersebut maka rumusan masalah dalam penelitian ini adalah :

1) Bagaimana proses pembelajaran Ilmu Pengetahuan Alam (IPA) dikelas I Madrasah Ibtidaiyah An-Nur Kota Cirebon?

2) Bagaimana penggunaan media gambar pada mata pelajaran Ilmu Pengetahuan Alam (IPA) dikelas I Madrasah Ibtidaiyah An-Nur Kota Cirebon?

3) Bagaimana peningkatan hasil belajar Ilmu Pengetahuan Alam (IPA) dengan menggunakan media gambar di kelas I Madrasah Ibtidaiyah An-Nur Kota Cirebon?

2.4 Tujuan Penelitian

1) Agar mengetahui proses pembelajaran Ilmu Pengetahuan Alam (IPA) di kelas I Madrasah Ibtidaiyah An-Nur Kota Cirebon 
2) Agar mengetahui penggunaan media gambar pada mata pelajaran Ilmu Pengetahuan Alam (IPA) di kelas I Madrasah Ibtidaiyah An-Nur Kota Cirebon

3) Agar mengetahui peningkatan hasil belajar Ilmu Pengetahuan Alam (IPA) dengan menggunakan media gambar di kelas I Madrasah Ibtidaiyah An-Nur Kota Cirebon.

\section{Hipotesis Penelitian}

Secara umum hipotesis dari penelitian ini adalah dengan menggunakan media gambar sebagai media pembelajaran yang dapat meningkatkan hasil belajar IPA siswa kelas I MI An-Nur Kota Cirebon.

Secara khusus hipotesis dari penelitian ini adalah sebagai berikut :

1) Penggunaan media gambar dapat meningkatkan hasil belajar IPA dalam materi tubuh yakni mengenal bagian-bagian tubuh dan dapat menyebutkan bagian-bagian tubuh serta kegunaannya.

2) Penggunaan media gambar dapat meningkatkan hasil belajar IPA dalam pemahaman cara merawat tubuh dengan baik dan benar yakni dengan praktik mencuci tangan dengan sabun.

3) Penggunaan media gambar dapat meningkatkan hasil belajar IPA yakni dalam pemahaman kebutuhan tubuh, siswa dapat menyebutkan apa saja yang dibutuhkan tubuhnya agar tumbuh sehat.

\section{Manfaat Penelitian}

Dengan adanya penelitian yang menjadi salah satu syarat untuk menyelesaikan program pendidikan strata satu (S1) pada jurusan Pendidikan Guru Madrasah Ibtidayah (PGMI), Fakultas Ilmu Tarbiyah dan Keguruan (FITK) Institut Agama Islam Negeri (IAIN) Syekh Nurjati Cirebon. Penelitian akan bermanfaat :

\subsection{Manfaat Teoritis}


Penelitian ini merupakan wujud dan sumbangsih nyata terhadap pengembangan ilmu pengetahuan dalam rangka penyelenggaraan dalam proses pembelajaran efektif dan menyenangkan yang menekankan pada partisipasi aktif siswa sebagai warga belajar yang dilakukan dengan perencanaan matang, kelengkapan alat, bahan dan media pembelajaran yang digunakan, pemanfaatan lingkungan serta sarana dan prasarana belajar yang memadai

\subsection{Manfaat Praktis}

1) Bagi siswa, meningkatkan aktivitas belajar siswa dikelas I MI An-Nur Kota Cirebon dengan menggunakan media gambar.

2) Bagi guru, mengetahui hasil belajar siswa dengan menggunakan media gambar pada mata pelajaran IPA dikelas I MI An-Nur Kota Cirebon. Guru dapat mengembangkan profesionalismenya dalam pelaksanaan proses pembelajaran yang menyenangkan.

3) Bagi sekolah, hasil penelitian dapat dijadikan tolak ukur pengambilan kebijakan dalam rangka perbaikan proses pembelajaran yang dilaksanakan guru sehingga tujuan penyelenggaraan pendidikan di sekolah dapat dicapai secara optimal.

4) Bagi peneliti, mengetahui gambaran proses penggunaan media gambar dengan hasil belajar siswa kelas I MI An-Nur Kota Cirebon, dan menambah wawasan pengetahuan peneliti bahwa media gambar sangat efektif digunakan dalam pembelajaran IPA dikelas I.

\section{Landasan Teori}

\section{Ilmu Pengetahuan Alam di SD/MI}

\subsection{Hakikat Pembelajaran Ilmu Pengetahuan Alam (IPA)}

Pengetahuan adalah segala sesuatu yang diketahui oleh manusia. Sedangkan ilmu adalah alat bantu yang digunakan manusia untuk memecahkan permasalahan dalam kehidupan sehari-hari. Pada mulanya hanya dikenal dua cabang utama ilmu, yaitu filsafat alam dan filsafat moral. 
Sains atau ilmu pengetahuan alam adalah ilmu yang pokok bahasannya adalah alam dengan segala isinya. Adapun hal-hal yang dipelajari dalam sains adalah sebab-akibat, yaitu hubungan kausal dari kejadian-kejadian yang terjadi di alam.

IPA sebagai mata pelajaran di SD/ MI merupakan materi yang "wajib" diajarkan. Para guru dan calon guru perlu mendalami hakikat IPA sebagai bagian dari materi IPA. IPA tidak hanya berbicara tentang alam, sifat, struktur, perubahan, dan energi yang terjadi, tetapi IPA harus mampu membangun karakter dan sikap yang telah dicontohkan oleh para saintis. Para saintis dalam proses membangun teori dalam ilmu pengetahuan tidak lepas dari sikap jujur, sabar dan tabah, teliti, kritis, mencari, bertanya, menerima kritik, tidak menerabas, dan sejenisnya. Karakter seperti ini perlu dibangun selama pengajaran IPA di sekolah (Wahidin, $2006: 2$ ).

\section{Media Pembelajaran}

2.1 Hakikat Media Pembelajaran

Ditinjau dari prosesnya pendidikan adalah komunikasi, karena dalam proses pendidikan terdapat komunikator, komunikan, dan pesan (message), yakni sebagai komponen-komponen komunikasi. Istilah komunikasi atau dalam bahasa inggris communication berasal dari kata latin communicatio, yang berarti pemberitahuan, pemberian bagian (dalam sesuatu, pertukaran, dimana si pembicara mengharapkan pertimbangan atau jawaban dari pendengarnya; ikut mengambil bagian. Kata sifatnya communis artinya bersifat umum atau bersama-sama. Kata kerjanya communicare; artinya berdialog, berunding atau bermusyawarah (Onong Uchjana Effendy, 1994:9 dan Anwar Arifin 1992:19-20) dalam Munadi (2010 : 2). Jadi, secara konseptual arti komunikasi itu sendiri sudah mengandung pengertian pemberitahuan (dan menyebarkan) berita, pengetahuan, pikiran-pikiran, nilai-nilai dengan maksud untuk menggugah partisipasi agar hal-hal yang diberitahukan itu menjadi milik bersama.

\section{Setting Penelitian}


Adapun lokasi yang menjadi tempat penelitian adalah di kelas I MI AnNur Kota Cirebon. Peneliti melakukan penelitian selama 3 bulan, terhitung dari tanggal 26 Mei sampai dengan 26 Agustus 2015. Peneliti melakukan penelitian ini dikelas I MI An-Nur Kota Cirebon. Jumlah siswa dikelas I MI An-Nur berjumlah 23 siswa, terdiri dari 14 laki-laki dan 9 perempuan.

Penelitian ini merupakan bentuk reflektif berupa tindakan tertentu agar dapat memperbaiki praktik pembelajaran di kelas secara efektif dan efisien serta profesional.

Dalam melakukan penelitian tindakan kelas ini saya sebagai peneliti menggunakan siklus menurut Kemis (Rochiati Wiratmaja) sebagai rencana tindakan dalam penelitian tindakan kelas.

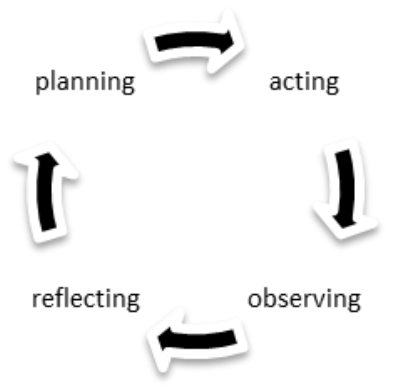

Gambar 3.1 siklus kemis ( Rochiati Wiraatmaja ) sebagai rencana tindakan PTK. (Mulyasa, 2012 :112)

Penelitian tindakan kelas ini juga menggunakan pendekatan saintifik dalam setiap tindakan siklusnya, karena penggunaan media gambar sangat efektif apabila menggunakan pendekatan saintifik, siswa akan berperan aktif dalam pembelajaran, seperti bekerja kelompok, mengamati dan menyimpulkan materi pelajaran yang mereka dapat.

\section{Instrumen Penelitian}

Instrumen penelitian dalam tindakan kelas ini adalah lembar observasi, soal tes, Foto dan Arsip

\section{Teknik Analisis Data}


Cara menghitung data kuantitatif yang diperoleh dari hasil tes siswa secara individu dioalah dengan mencari rata-ratanya.

Kriteria tingkat keberhasilan aktivitas/respon siswa menurut Sudjana $(2004: 78)$

Ketuntasan belajar klasikal $=\frac{\text { skor yang dilaksanakan }}{\text { skor maksimal dari indikator yang ada }} \times 100 \%$

\begin{tabular}{|c|c|c|c|}
\hline $\begin{array}{c}\text { Pencapaian } \\
\text { Tujuan }\end{array}$ & Skor & Kualifikasi & Keberhasilan \\
\hline $85-100 \%$ & 3 & Baik & Berhasil \\
\hline $70-84 \%$ & 2 & Cukup & Cukup Berhasil \\
\hline $50-69 \%$ & 1 & Kurang & Tidak Berhasil \\
\hline
\end{tabular}

Keterangan :

$85-100 \%=$ Berhasil

70-84\% = Cukup Berhasil

50-69 = Tidak Berhasil

Tahap awal dari penelitian ini adalah peneliti mengadakan pengamatan hasil nilai ujian tengah semester siswa akhir ajaran 2014-2015 dengan nila ratarata pembelajaran IPA adalah 65\%. Dari hasil pengamatan tersebut ternyata nilai harian pembelajaran IPA dikelas I MI An-Nur Kota Cirebon masih rendah.

Pertama, dalam pembelajaran guru melakukan apersepsi diperoleh ratarata 60\%; kedua, siswa bertanya kepada guru dan siswa lain diperoleh rata-rata sebesar 60\%; ketiga, menjawab pertanyaan guru ketika PBM berlangsung mendapatkan nilai rata-rata sebesar $62 \%$; keempat, memanfaatkan sumber belajar yang ada mendapatkan nilai rata-rata sebesar 65\%; kelima, bekerjasama dengan kelompok (pada Pra Siklus ini tidak ada belajar kelompok); keenam, keaktifan memberikan tanggapan/respon yang baik mendapatkan nilai rata-rata sebesar $63 \%$; ketujuh mengerjakan soal tes yang diberikan guru $72 \%$ dan yang terakhir dengan indikator siswa mampu menyimpulkan materi yang diberikan mendapatkan nilai rata-rata sebesar $60 \%$. 
Dari hasil tes Pra Siklus diperoleh rata-rata kelas 60,04 hasil evaluasi Pra Siklus menunjukan pemahaman siswa terhadap pelajaran IPA secara umum rataratanya masih kurang apa yang distandarkan untuk mata pelajaran IPA yaitu minimal nilai 70 .

Dari hasil belajar diatas menunjukan bahwa proses pembelajaran pada Pra Siklus belum tuntas karena sesuai dengan yang dikemukakan oleh Depdiknas (2006) bahwa proses pembelajaran dikatakan tuntas apabila 85\% siswa dikelas memperoleh nilai $\geq 70$

Rata-rata aktivitas siswa pada siklus 1 dapat dideskripsikan sebagai berikut : Pertama, menanggapi apersepsi yang diberikan guru diperoleh rata-rata 80\%; kedua, siswa bertanya kepada guru dan siswa lain diperoleh rata-rata sebesar 70\%; ketiga, menjawab pertanyaan guru ketika PBM berlangsung mendapatkan nilai rata-rata sebesar 75\%; keempat, memanfaatkan sumber belajar yang ada mendapatkan nilai rata-rata sebesar 80\%; kelima, bekerjasama dengan kelompok mendapatkan nilai rata-rata 73; keenam, keaktifan memberikan tanggapan/respon yang baik mendapatkan nilai rata-rata sebesar $75 \%$; ketujuh mengerjakan soal tes yang diberikan guru $75 \%$ dan yang terakhir dengan indikator siswa mampu menyimpulkan materi yang diberikan mendapatkan nilai rata-rata sebesar $70 \%$.

Dari data yang diperoleh diatas, setelah dianalisis ternyata rata-rata yang diperoleh untuk Siklus I adalah 74,75\% yang dinyatakan cukup berhasil.

Perolehan hasil belajar pada siklus I tindakan I diperoleh hasil rata-ratanya 72,17 dari 23 siswa. Hasil evaluasi siklus I nilai rata-rata tersebut cukup sedikitnya sudah dapat melampaui kriteria ketuntasan mengajar mata pelajaran IPA yaitu 70. Akan tetapi masih ada 5 siswa yang belum mencapai nilai 70. Siswa itu adalah Aisyah, Akmal, Safinah, Sekar, dan Syarif. Mereka masih belum mendapatkan nilai sesuai KKM yaitu 70, rata-rata nilai mereka adalah 60 .

Skor rata-rata aktivitas siswa pada siklus II dapat disimpulkan bahwa pada indikator pertama, menanggapai apersepsi yang diberikan guru diperoleh rata-rata sebesar $87 \%$ dan termasuk kategori baik; kedua, siswa bertanya kepada guru dan siswa lain diperoleh rata-rata sebesar $87 \%$; ketiga, menjawab pertanyaan guru ketika PBM berlangsung mendapatkan nilai rata-rata sebesar 85\%; keempat, 
memanfaatkan sumber belajar yang ada mendapatkan nilai rata-rata sebesar $87 \%$; kelima, bekerjasama dengan kelompok mendapatkan nilai rata-rata 80\%; keenam, keaktifan memberikan tanggapan/respon yang baik mendapatkan nilai rata-rata sebesar $86 \%$; ketujuh mengerjakan soal tes yang diberikan guru $87 \%$ dan yang terakhir dengan indikator siswa mampu menyimpulkan materi yang diberikan mendapatkan nilai rata-rata sebesar $80 \%$. Dan semuanya mendapat kriteria cukup dan baik serta dinyatakan berhasil.

Berdasarkan hasil observasi rata-rata aktivitas siswa secara individu yang memperoleh nilai baik berjumlah 20 orang, sedangkan siswa yang memperoleh nilai cukup berjumlah 3 orang.

Berdasarkan hasil keseluruhan dari mulai pra siklus, siklus I sampai siklus II, hasil belajar yang diperoleh siswa kelas I dengan menggunakan media gambar mengalami peningkatan hasil belajar setiap siklusnya. Pada pra siklus diperoleh rata-rata 60,04, siklus I diperoleh rata-rata 72,17. Nilai tersebut mengalami peningkatan $12,13 \%$, siklus II diperoleh nilai rata-rata 86,52 nilai tersebut mengalami peningkatan sebesar 14,35 . 


\section{DAFTAR PUSTAKA}

Arikunto, Suharsimi. 2012. Dasar-dasar Evaluasi Pendidikan Edisi 2. Jakarta : PT Bumi Aksara

Arikunto, Suharsimi. 2006. Prosedur Penelitian Suatu Pendekatan Praktik. Jakarta : Rhineka Cipta

Arsyad, Azhar. 2014. Media Pembelajaran. Jakarta : PT Rajawali Pers

Gintings, Abdurrakhman. 2010. Belajar dan Pembelajaran. Bandung : Humaniora

Helmiati. 2013. Micro Teaching (Melatih Keterampilan Dasar Mengajar). Yogyakarta: Aswaja Pressindo

Khairani, Makmum. 2014. Psikologi belajar. Yogyakarta: Aswaja Pressindo

Khalifah, Mahmud dkk. 2015. Menjadi Guru yang Dirindu. Surakarta : Ziyad

Ma'mur, Jamal. 2014. Tips Membangun Komunitas Belajar di Sekolah. Yogyakarta: DIVA Press.

Majid, Abdul. 2012. Perencanaan Pembelajaran(Mengembangkan Standar Kompetensi Guru). Bandung : PT Remaja Rosdakarya

Mulyasa. 2012. Praktik Penelitian Tindakan Kelas. Bandung : PT Remaja Rosdakarya

Munadi, Yudhi. 2010. Media Pembelajaran. Jakarta : Gaung Persada

Muslich, Masnur. 2011. Melaksanakan PTK itu Mudah. Jakarta : Bumi Aksara

Ruswandi Uus, dkk. 2008. Landasan Pendidikan. Bandung : Insan Mandiri

Salahudin, Anas. 2015. Penelitian Tindakan Kelas. Bandung : Pustaka Setia

Silberman, Mel. 2013. Active Learning 101 Cara Belajar Siswa Aktif. Bandung : Nuansa Cendekia

Sudjana, Nana. 2004. Penilaian Hasil Proses Belajar Mengajar. Bandung : Remaja Rosdakarya

Sudjana, Nana dan Rivai, Ahmad. 2009. Media Pengajaran. Bandung : Sinar Baru Algensindo

Sudjiono, Anas. 2013. Pengantar Evaluasi Pendidikan. Jakarta: Rajawali Press. 
Sulaeman, Momon. 2004. Lebih Dekat dengan Alam (Sains untuk SD/MI kelas I jilid I). Jakarta Pusat : PT. Setia Purnama Inves

Sulistyanto, Heri. 2008. Ilmu Pengetahuan Alam. Jakarta : Pusat Perbukuan, Departemen Pendidikan

Syaodih, Nana. 2006. Metode Penelitian Pendidikan. Bandung : PT. Remaja Rosdakarya

Undang-undang Republik Indonesia Nomor 12 Tahun 2005 tentang Sistem Pendidikan Nasional pasal hal 3. Jakarta : Cemerlang.

Undang-undang Republik Indonesia Nomor 20 Tahun 2003 tentang Sistem Pendidikan Nasional pasal hal 3. Jakarta : Cemerlang.

Wahidin. 2006. Metode Pendidikan Ilmu Pengetahuan Alam. Bandung : Sangga Buana

Wisudawati, Sulistyowati. 2014. Metodologi Pembelajaran IPA. Jakarta : Bumi Aksara 